\title{
CRYPTOSPORIDIUM AND OTHER ZOONOTIC PARASITES IN OREOCHROMIS NILOTICUS IN ASSIUT GOVERNORATE
}

\author{
M.A.M. AMMAR and M.I. ARAFA
}

Animal Health Research Institute, Assiut Regional Lab.

Email: mohsenpara22@yahoo.com

\begin{tabular}{|c|c|}
\hline & ABSTRACT \\
\hline Received at: $30 / 9 / 2013$ & $\begin{array}{l}\text { This study was carried out on } 120 \text { Oreochromis niloticus fish ( } 60 \text { wild and } 60 \text { cultured). } \\
\text { The fish were randomly collected, from different areas of Assiut Governorate as well as } \\
\text { from some fish farms. They were used to investigate the prevalence of } \\
\text { Cryptosporidium and other zoonotic parasites in } O \text {. niloticus. Examination of gills, } \\
\text { muscles and the contents of the gastrointestinal tract revealed highest parasitic } \\
\text { infestation rate }(80 \%) \text { in wild compared to }(55 \%) \text { in cultured } O \text {. niloticus. The } \\
\text { prevalence of the isolated parasites in wild and cultured } O \text {. niloticus was as follows: } \\
\text { Cryptosporidium spp. } 15.0 \% \text { and } 23.3 \% \text { respectively; Acanthocephela } \\
\text { (Acanthocentius tilapae) } 8.3 \% \text { and } 9.2 \% \text { respectively; microscopic encysted } \\
\text { metacercariae } 88.3 \% \text { and } 26.7 \% \text { respectively while macroscopic encysted } \\
\text { metacercariae detected only in wild } O \text {. niloticus } 40 \% \text {. Killing factors (temperatures, } \\
\text { solutions and processing methods) were studied on encysted metacercariae (EMC) in } \\
\text { O. niloticus killing criteria followed the movability index (MI) from } 1.000 \text { within } 24 \\
\text { hours. Muscle pieces containing viable EMC were incubated in different } \\
\text { concentrations of NaCl, acetic acid or commercial vinegar at room temperature. The } \\
\text { MI was } \leq 1 \text { (killing effect) within } 1,2 \text { hours for } 30 \% \text { and } 20 \% \text { of NaCl respectively and } \\
1 \text {, } 6 \text { and } 12 \text { hours for } 5,2.5 \text { and } 1.25 \% \text { of acetic acid, respectively while commercial } \\
\text { vinegar has MI } \geq 1 \text { (no killing effect) at } 5 \% \text {. Storage of } O \text {. niloticus at (-10 }{ }^{\circ} \text { ) resulted in } \\
\text { killing the EMC after } 12 \text { hours of storage while storage at } 5{ }^{\circ} \mathrm{C} \text { for } 24 \text { hours has no } \\
\text { killing effect. Dry salting of } O \text {. niloticus could kill the EMC within one hour of salt } \\
\text { contact, while marination in } 5 \% \text { acetic acid for one minute resulted in eradication of } \\
\text { EMC after } 2 \text { hours of treatment with barely detected acetic acid odor and significant } \\
\text { reduction in muscle pH }(P<0.05 \text {.). }\end{array}$ \\
\hline
\end{tabular}

Keywords: Cryptosporidium, zoonotic parasites, fish, Killing factors, processing methods, encysted metacercariae (EMC).

\section{INTRODUCTION}

Fish meat demand as human food is increasing especially in the developing countries where people income is low. World fish production has grown tremendously in the second half of the 20th century (Pillay, 1990). Egyptian per capita fish consumption is more than doubled from below $7 \mathrm{~kg}$ in 1990 to over $14 \mathrm{~kg}$ in 2002, (Suloma and Ogata, 2006). Tilapia is the predominant aqua-cultured finfish in Egypt and represented $14.5 \%$ of the coounty's total fish landing and is a componant of traditional Egyptian diet (Green et al., 2002).

Salted, salt fulminated, smoked and fried fish are the favorite traditional fish dishes on the Egyptian people. The effect of some traditional processing methods on EMC is remained uncertain. Eating the EMC in row or under processed fish constitute a zoontic risk (Huss et al., 2003).
A multitude of parasites have been reported in fish, but only a few species are capable of infecting human (Adams et al., 1997). Recent reports suggest that fishes act as a source of serious human parasitic infectious diseases (EFSA, 2010). Fish borne parasites infecting human results from food habits of the people by consuming raw, partially cooked, slightly salted or smoked fish (Abd El-Maksoud, 1992). Members of the genus Cryptosporidium are parasites of the intestinal tracts of fishes, reptiles, birds, and mammals. People may be infected by consuming contaminated water or food. Cryptosporidiosis is an emerging disease in both wild and farmed fish in numerous countries worldwide (Sitja-Bobadilla et al., 2005). Relatively little is known about the prevalence and geographic distribution of Cryptosporidium isolates that infect fish in Egypt. Heat inactivation of parasites proved effective for eliminating the risk of parasitosis but trematodes possessed a higher heat resistance (Hus et al., 2003). So far fish processors need alternative 
easy, fast, cheap and effective measures for eradication of EMC. However the appropriate inactivation technologies in freshwater fish are not well established. Therefore the present study aimed to:

- Document the prevalence of Cryptosporidium and other zoonotic parasites in one of the most common edible fishes (Oreochromis niloticus) that might cause public health problems, if these fishes were eaten improperly cooked.

- Investigate the effect of some killing factors: temperatures, solutions and processing methods on encysted metacercariae (EMC).

\section{MATERIAL and METHODS}

\section{1- Samples:}

A total number of 120 specimens of $O$. niloticus $(60$ farmed fish \& 60 wild fish) were randomly collected from different localities of the River Nile and from some fish farms at Assiut Governorate.

\section{2- Parasitological examination:}

(A) Macroscopic examination:

Macroscopic examination was carried out either by naked eye or by the magnifying hand lens ( $2 \mathrm{X}$ and $4 \mathrm{X}$ ) for detection of encysted metacercariae (EMC) in musculature and gills (Mahdy et al., 1995).

\section{(B) Microscopic examination:}

Muscles were screened for the presence of EMC by compression method in which snips were taken from muscles of each part of fish body (head, trunk and tail). Each piece was compressed between two microscopic glass slides and examined microscopically for the presence of EMC (Sayasone et al., 2007).

Metacercariae were identified to genus level based on the morphological details, their dimensions, shape of cysts, site of infection, and shape and contents of excretory bladder under light microscopy (Amer, 1996; Sohn et al., 2005 and Elsheikha and Elshazly, 2008).

The stomachs and intestines were dissected and placed in separate Petri dishes with physiological saline solution, and washed by saline solution. Mucosal scrapings were collected and centrifuged for concentration of oocysts (Waldman et al., 1986). Smears were done from the sediment and stained by a modified Zeil- Neolsen acid-fast (Henriksen and Pohlenz, 1981).

The collected Acanthocephela were first washed in saline solution, refrigerated in cold water for 12 hours to protrude its proboscis, were relaxed and fixed in AFA (Alcohol formalin acetic acid), dehydrated and mounted (Pritchard and Kruse, 1982).

3- Studying the effect of sodium chloride $(\mathrm{NaCl})$, acetic acid and vinegar on encysted metacercariae in $O$. niloticus muscle pieces:

Ten pieces (about $1 \mathrm{~cm}^{3}$ each) of heavily infected fish muscles containing active encysted metacercariae were soaked in a $20 \mathrm{ml}$ solution of $(40,20,10,5,2.5$, 1.25 and $0.3 \%$ ) concentrations of acetic acid, $(40,20,10,5,2.5,1.25$ and $0.3 \%) \mathrm{Na} \mathrm{Cl}$ or $(5,2.5$, 1.25 and $0.3 \%$ ) vinegar, individually in a plastic plate. Infected fish muscle pieces containing active encysted metacercariae were soaked in $20 \mathrm{ml}$ distilled water as a control. For each concentration and control the muscle pieces were examined at $0,1,2,4,6,12,18$ and $24 \mathrm{~h}$ of soaking and transferred to another plate contains $20 \mathrm{ml}$ of $0.89 \% \mathrm{Na} \mathrm{Cl}$ and examined for metacercariae movement using light microscope. The assessment of the effect of treatment was done using the movability index (MI) recommended by (Prawang, 2001) and the killing criterion described by (Wongsawad et al., 2005). Since MI value $\leq 1.0$ within $24 \mathrm{~h}$ refers to the death while MI $>1.0$ refers to the survival of the metacercariae.

4- Studying the effect of storage temperature or different processing methods on EMC:

Freshly caught $O$. niloticus (50 -70gm each) were examined for presence of active EMC. A sufficient number of highly infected fish were eviscerated, washed and divided into the following groups:

GA were put in tightly closed plastic bags and subdivided into GA1 (were refrigerated at $5^{\circ} \mathrm{C}$ ) and GA2 (were frozen at $-10{ }^{\circ} \mathrm{C}$ ). GB were soaked in acetic acid $5 \%$ for one minute at room temerature. $\mathrm{GC}$ were dry salted at room temperature using $\mathrm{NaCl}$ $(\mathrm{NaCl} /$ fish $=3 / 10 \mathrm{gm})$. GD was control group. The assessment of the effect of different factors on EMC was done by reporting the MI at $0,1,2,4,6,12,18$ and 24h according to (Prawang, 2001) and (Wongswad, 2005).

5- Evaluation of the effect processing fish with acetic acid on the chemical and sensory quality of processed fish:(Sallam, 2007)

(A)- pH measurement: :( Sallam, 2007)

Ten grams of each sample were blended with $20 \mathrm{ml}$ distilled water in a blender for $30 \mathrm{~s}$ and $\mathrm{pH}$ value of fish homogenate was measured by a digital $\mathrm{pH}$-meter (Gallenhamp No.101284) standardized at pH 4 and 7.

(B)- Sensory assessment: (Sallam, 2007)

Fish samples soaked in acetic acid for one minute as well as control samples were separately wrapped with aluminum foil, cooked in steaming pot until the core temperature of each sample reached $70 \dot{c}$. stick water was drained and allowed to cool to room temperature (25-28 $\dot{c})$. The acceptability of cooked samples was 
evaluated by 5 semi-trained panelists.

Panelists were asked to evaluate the overall acceptability with regard to appearance, odour intensity, flavour and aftertaste, tenderness, juiciness, off-odour, and off-flavour according eight-point hedonic scoring scale. Samples receiving overall scores of more than 4 were considered acceptable, while a score between 3 and 4 was considered the borderline of acceptability. The packaged SPSS program for windows version 12.0.1 was used for statistical analysis according to (SPSS 2007). Data were expressed as mean \pm standard error (SE). Differences between groups were determined by means of a Student " $t$ "-test. Significance level was set at $\mathrm{P}<0.05$.

\section{RESULTS}

Table 1: Prevalence of different zoonotic parasites in examined fish.

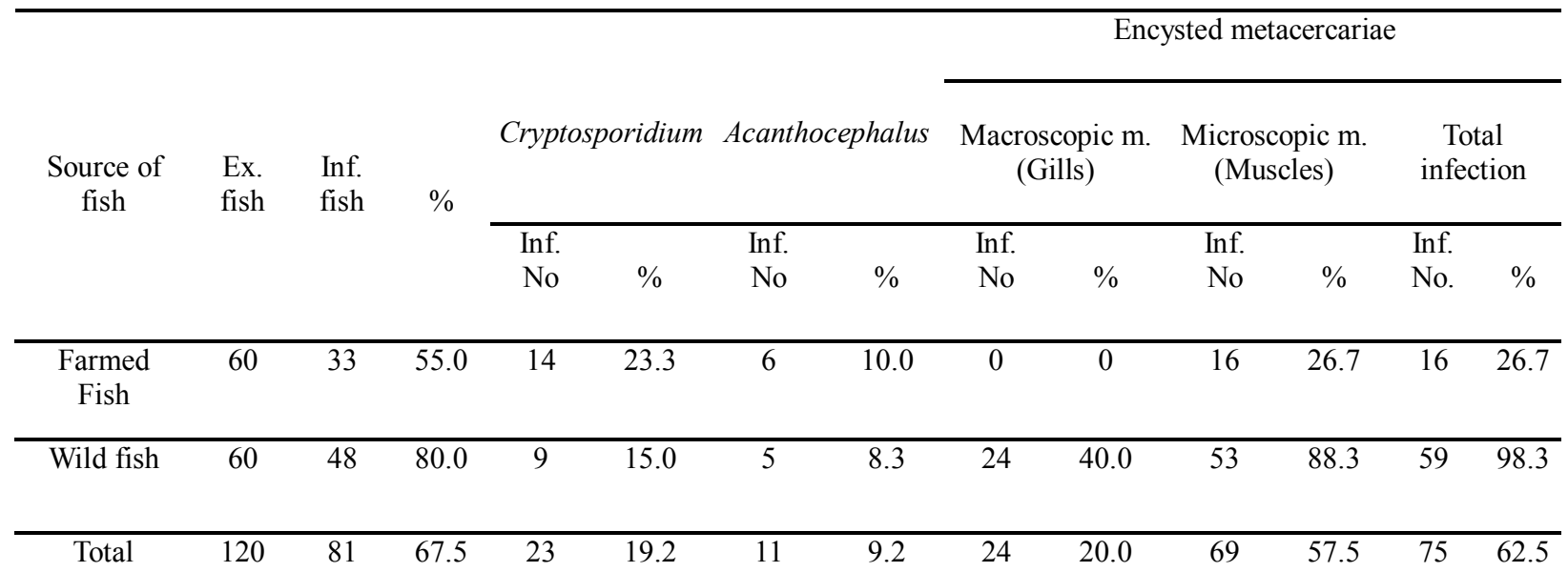

Table 2: Prevalence of different metacercariae detected in examined fish.

\begin{tabular}{|c|c|c|c|c|c|c|c|c|c|c|c|c|}
\hline \multirow{3}{*}{$\begin{array}{l}\text { Source } \\
\text { of fish }\end{array}$} & \multicolumn{12}{|c|}{ Infected Fishes } \\
\hline & \multicolumn{2}{|c|}{$\begin{array}{c}\text { Total } \\
\text { Macroscopic } \\
\text { meta. }\end{array}$} & \multicolumn{2}{|c|}{$\begin{array}{c}\text { Total } \\
\text { Microscopic } \\
\text { meta. }\end{array}$} & \multicolumn{2}{|c|}{$\begin{array}{c}\text { Mixed } \\
\text { infection }\end{array}$} & \multicolumn{2}{|c|}{$\begin{array}{c}\text { Single } \\
\text { Macroscopic } \\
\text { meta. }\end{array}$} & \multicolumn{2}{|c|}{$\begin{array}{c}\text { Single } \\
\text { Microscopic } \\
\text { meta. }\end{array}$} & \multicolumn{2}{|c|}{$\begin{array}{c}\text { Total } \\
\text { infection }\end{array}$} \\
\hline & $\begin{array}{c}\text { infected } \\
\text { No. }\end{array}$ & $\%$ & $\begin{array}{c}\text { infected } \\
\text { No. }\end{array}$ & $\%$ & $\begin{array}{l}\text { infected } \\
\text { No. }\end{array}$ & $\%$ & $\begin{array}{c}\text { infected } \\
\text { No. }\end{array}$ & $\%$ & $\begin{array}{c}\text { infected } \\
\text { No. }\end{array}$ & $\%$ & $\begin{array}{c}\text { infected } \\
\text { No. }\end{array}$ & $\%$ \\
\hline $\begin{array}{l}\text { Farmed } \\
\text { Fish }\end{array}$ & 0 & 0 & 16 & 26.7 & 0 & 0 & 0 & 0 & 16 & 26.7 & 16 & 26.7 \\
\hline $\begin{array}{l}\text { Wild } \\
\text { fish }\end{array}$ & 24 & 40.0 & 53 & 88.3 & 18 & 30.0 & 6 & 10.0 & 35 & 58.3 & 59 & 98.3 \\
\hline Total & 24 & 20.0 & 69 & 57.5 & 18 & 15.0 & 6 & 5.0 & 51 & 42.5 & 75 & 62.5 \\
\hline
\end{tabular}

Table 3: Prevalence of different species of metacercariae in examined fish.

\begin{tabular}{|c|c|c|c|c|c|c|}
\hline \multirow{2}{*}{ Types of metacercariae } & \multicolumn{2}{|c|}{ Farmed fish } & \multicolumn{2}{|c|}{ Wild fish } & \multicolumn{2}{|c|}{ Total } \\
\hline & $\begin{array}{l}\text { N0. of } \\
\text { Inf. fish }\end{array}$ & $\%$ & $\begin{array}{l}\text { N0. of } \\
\text { Inf. fish }\end{array}$ & $\%$ & $\begin{array}{l}\text { N0. of } \\
\text { Inf. fish }\end{array}$ & $\%$ \\
\hline Microscopic m: & 16 & 26.7 & 53 & 88.3 & 69 & 57.5 \\
\hline 1-Prohemistomum spp.m & 9 & 15.0 & 33 & 55.0 & 42 & 35.0 \\
\hline 2- Haplorchis spp.m & 0 & 0 & 3 & 5.0 & 3 & 2.5 \\
\hline 3- Diplostomum spp.m & 7 & 11.7 & 17 & 28.3 & 24 & 20.0 \\
\hline Macroscopic m: & 0 & 0 & 24 & 40.0 & 24 & 20.0 \\
\hline 1-Clinostomum & 0 & 0 & 23 & 38.3 & 23 & 19.2 \\
\hline phalacrocoracis & 0 & 0 & 1 & 1.7 & 1 & 0.8 \\
\hline 2-Clinostomum tilapiae & & & & & & \\
\hline
\end{tabular}


$\underline{\text { Assiut Vet. Med. J. Vol. } 59 \text { No. } 139 \text { October } 2013}$

Table 4: Effect of chemicals on movability index (MI) of ECM.

\begin{tabular}{ccccccc}
\hline \multirow{2}{*}{ Parameter } & \multicolumn{2}{c}{ Acetic acid } & \multicolumn{2}{c}{ Sodium chloride } & \multicolumn{2}{c}{ Vinegar } \\
\cline { 2 - 7 } & Conc & $\begin{array}{c}\text { Duration in } \\
\text { hours }\end{array}$ & Conc. & $\begin{array}{c}\text { Duration in } \\
\text { hours }\end{array}$ & Conc & $\begin{array}{c}\text { Duration in } \\
\text { hours }\end{array}$ \\
\hline \multirow{2}{*}{ MI $\leq 1$} & $5 \%$ & 1 & $30 \%$ & 1 & - & - \\
\cline { 2 - 7 } & $2.5 \%$ & 6 & $20 \%$ & 2 & - & - \\
\cline { 2 - 7 } & $1.25 \%$ & 12 & - & - & & 24 \\
\hline & $0.6 \%$ & 24 & $10 \%$ & 24 & $5 \%$ & 24 \\
\hline
\end{tabular}

Table 5: Effect of processing or storage temperature on movability index (MI) of EMC.

\begin{tabular}{cccc}
\hline \multicolumn{2}{c}{ MI $\leq 1$} & & MI $\geq 1$ \\
\hline Processing & Duration in hours & processing & Duration in hours \\
\hline $\begin{array}{c}\text { Soaking in acetic acid 5\% } \\
\text { for 30s }\end{array}$ & $\begin{array}{c}2 \text { hours after } \\
\text { treatment }\end{array}$ & $\begin{array}{c}\text { Soaking in acetic acid } \\
2 \% \text { for } 60 \mathrm{~s}\end{array}$ & 24 hour after treatment \\
\hline Dry salting & 1 & Storage at 5ć & 24 \\
\hline Storage at -10ć & 12 & & \\
\hline
\end{tabular}

Table 6: Effect of processing O.nioticus with acetic acid on $\mathrm{pH}$ and sensory quality.

\begin{tabular}{|c|c|c|c|c|c|c|c|}
\hline \multirow{2}{*}{ Parameters. } & \multirow{2}{*}{$\mathrm{pH}$} & \multicolumn{6}{|c|}{ Sensory evacuations } \\
\hline & & $\begin{array}{l}\text { Odour } \\
\text { intensity }\end{array}$ & Juicen-ess & Tenderness & Appearance & $\begin{array}{c}\text { Unpleasant } \\
\text { odour }\end{array}$ & $\begin{array}{c}\text { Overall } \\
\text { acceptability }\end{array}$ \\
\hline \multirow{2}{*}{ Mean Treat. } & \multirow{2}{*}{$5.07 \pm 0.22$} & $5.33 \pm 0.33$ & $7.67 \pm 0.33$ & $7.33 \pm 0.33$ & $7.00 \pm 0.00$ & $5.00 \pm 0.00$ & $31.67 \pm 0.22$ \\
\hline & & $\begin{array}{l}\text { Slight } \\
\text { intense }\end{array}$ & $\begin{array}{l}\text { Extreme } \\
\text { juicy }\end{array}$ & Very tender & Moderate & Barely detected & Acceptable \\
\hline \multirow{2}{*}{ Mean. Cont. } & \multirow{2}{*}{$6.03 \pm 0.12$} & $6.67 \pm 0.33$ & $7.33 \pm 0.33$ & $5.67 \pm 0.33$ & $7.33 \pm 0.33$ & $6.00 \pm 0.00$ & $32.67 \pm 0.12$ \\
\hline & & $\begin{array}{c}\text { Very } \\
\text { intense }\end{array}$ & Very juicy & $\begin{array}{c}\text { Moderate } \\
\text { tender }\end{array}$ & Moderate & Not detected & Acceptable \\
\hline P-value & 0.027 & 0.092 & 0.211 & 0.065 & 0.211 & 0.0005 & 0.113 \\
\hline
\end{tabular}




\section{DISCUSSION}

Parasitic fauna of fishes respond strongly to alterations in the physical and chemical characteristics of aquatic environment and modifications in the physiological and biological conditions of hosts (Ferrari- Hoeinghaus et al., 2006).

The results of the present study showed that, parasite community of wild and farmed $O$. niloticus consisted of, one protozoon (Cryptosporidium spp. 19.2\%), one Acanthocephalan (Acanthocephalus spp 9.2\%) and five trematode metacercariae (Prohemistomum spp. $35.0 \%$, Diplostomum spp. 20.0\%, Haplorchis spp. $2.5 \%$, Clinostomum phalacrocoracis $19.2 \%$ and $C$. tilapiae $0.8 \%$ ).

The overall prevalence of examined fish was $67.5 \%$, highest infestation rate was detected in wild $O$. niloticus $80 \%$ compared to $55 \%$ in farmed one (table 1). Contrary to these results were recorded by (Eissa, et al., 1996) who reported that the infection rate in farmed and wild fish in Sharkia Governorate

was $67.33 \%$ and $42.33 \%$ respectively. Also Ibrahim (2012) recorded that the infection rate in farmed fish was $63.51 \%$ and in wild fish was $44.37 \%$ in Ismailia Governorate.

The difference of percentage may be attributed to the sanitary condition of the place, the location of the river from living place, number and class of people visiting the river and their purpose, biological pollution and snails propagation which act as intermediate hosts to complete the life cycle of some trematodes. In addition to good environmental conditions carried out by fish farmers in the study area.

Skinner (1982) mentioned that chronic exposure to pollutants or any environmental stress which lead to immuno-suppression through the release of corticosteroids make the fish more susceptible to any pathogenic organisms. This is considered the main factor responsible for the high rates of parasitic diseases in fish.

Examination of MZN stained intestinal contents smears in the present study revealed that 23 fish (19.2\%) were positive for Cryptosporidium $s p$. The infection rate in farmed fish was $23.3 \%$ while in wild fish it was $15.0 \%$ (table1). Gastric and intestinal cryptosporidiosis has been previously identified in 14 species of marine and freshwater fish (AlvarezPellitero et al., 2004 and Xiao et al., 2004). Hefnawy (1989) detected Cryptosporidium in $30 \%$ of Tilapia in Assiut. Al- Taee (2008) detected it in $28.97 \%$ in examined fish from Mosul. Abd-Allah (2009) detected $C$. parvum oocysts with infection rate of $13.75 \%$ in crayfish at Zagazig. Also Mahmood (2012) detected it in $16.9 \%$ of carp fish in Iraq. The variation in the rate of infections may be due to the genus and numbers of fish, time of samples collection and examination, the rate of contaminated water, stress exposed in addition to the methods used for the diagnosis.

On the other hand, highest infection rate in farmed fish may be related to food supply in addition to over crowding which leads to the high and quick spread of infectious diseases in farmed fish. Additionally, fish farming in rural areas is always integrated with poultry production and this might have contributed to the parasitic infection which some species may cross infect between fish and domestic poultry (Aiello and Mays 1998).

The appearance of detected Cryptosporidium oocysts after staining with modified Zeihl- Neelsen was bright red spherical oocysts with a diameter of $5.2 \mathrm{x}$ $4.4 \mu \mathrm{m}$, and that agree with the description by (Xiao et al., 2004 and O' Donghue, 2005).

Cryptosporidium lacks species host specificity (Xiao et al., 2004). Therefore, domestic and wild species of animals may be reservoirs of infection for susceptible human individuals, whether they are immunodeficient or immunologically competent. Accordingly, the infected fish play a role as reservoirs and can shed massive amount of infective oocysts to the aquatic environments, so this pathogen has been isolated worldwide from rivers, lakes and other sources of water (Baruš et al., 2002 and O' Donghue, 2005).

On the other hand adult worms of Acanthocephela were detected in $9.2 \%$ of examined fish, their infection rate in farmed and wild fish was $10.0 \%$ and $8.3 \%$ respectively (table 1 ). This result some what agrees with that of Eissa et al. (1996) and AbdelMawla and El-Ekiaby (2012) in both farmed and wild Tilapia, but high prevalence was detected in Tilapia by El- Naffar et al. (1983) $43.2 \%$ and Eissa et al. (2010) $46.9 \%$. Although, they disagreed with the prevalence, all agreed that $O$. niloticus is the only species of fish infested with Acanthocephala spp. through feeding on fresh water crustacean (Duijn, 1973). Ramadan (1991), mentioned that the kind of food is a fairly factor in determining the type of helminth parasites which can be found in a fish. Martin et al. (2009) reported that, high stocking densities favors increased parasite populations.

Natural infestation of man with Acanthocephala is rare, but possible where eating habits are unclean. In some cases they can cause great pain to the host if the proboscis completely perforates the gut wall. Subsequent natural infections with Acanthocephala have since been reported, (Tada et al., 1983). Eight species have been isolated from humans to date (Haustein et al., 2009).

Concerning to the prevalence of encysted metacercariae in the present work, total infection rate 
was $63.3 \%$. They were differentiated into microscopic encysted metacercariae $57.5 \%$ and macroscopic 20.0 $\%$ (table 1). These findings are nearly similar to those given by Arafa et al. (2005) 42.86\% Abd-El- Rahman (2005) 45\% and Abd-Allah (2009) 32.2\%. However, higher prevalence war recorded by Khattab (1990) $87.06 \%$ and Taher (2009) 84.75\%. Taher, (2009) suggested that such variation in prevalence may be related to the difference in the habitat, food supply, abundance of both aquatic snails (the intermediate host), and the aquatic piscivorous birds, which play the main role to complete the life cycle of some digenetic trematodes.

The highest infection rate with microscopic metacercariae was detected in wild fish (88.3\%), while macroscopic metacercariae were not detected in farmed fish (table1). The present authors suggest that such results may be related to the wide area of surface water of River Nile and their richness with aquatic snails (the intermediate host) and presence of aquatic birds around it is considered the most important points which lead to increase the infestation rate in wild fish.

Microscopic metacercariae detected in the present work were differentiated into: Prohemistomum $s p$. (35.0\%), Haplorchis sp. and (2.5\%) Diplostomum sp. $(20.0 \%)$, while macroscopic metacercariae detected in the present work were differentiated into: Clinostomum phalacrocoracis (19.2\%) and Clinostomum tilapiae (0.8\%).

Most of these metacercariae were detected previously by El- Shahawi (1983), El-Naffar, and El-Shahawi (1986), Hussein (2007) and Taher, (2009).

Trematode metacercariae are considered as one of the most common parasites infesting fish; some of these parasites may have zoonotic importance (Hernandez et al., 1998). Yellow grub (Clinostomum metacercariae) causing Halzoun like disease, while Prohemistomum vivax may causing death for human being (Nasr, 1941 and Williams and Jones, 1976).

The majority of human infections with trematode result from the consumption of raw or lightly cooked freshwater fish or shellfish containing viable metacercariae. Depending on the parasite species, these infections may occur in the liver, lungs, small intestine and occasionally brain or other tissues producing symptoms ranging in severity from mild to debilitating and life-threaten (Amin, 2005). In surveys a true picture of the prevalence in humans with these parasites is difficult to attain because of the similarity of their eggs of many species (Healy, 1970).

Encysted metacercaria (EMC) develop in O. niloticus as intermediate host. The effects of aberrant physico- chemical microenvironment (e.g. salt, vinegar and acetic acid) concentrations for different exposure times on EMC were studied. The in vitro investigation showed that the tested EMC were killed within 1,6 and 12 hour of incubation in 5, 2.5, and $1.25 \%$ acetic acid, respectively (Table 4 ). Acetic acid is generally recognized as safe by The United States Food and Drug Administration (FDA). Most research on individual or combined effect of acetic acid has focused on surface contamination of fish and fresh meat surface (Ahmed 1999). However, few studies directed toward the wormcidal effect of acetic acid. With The Far East Stellantchasmus falcatus EMC, Wongsawad et al. (2005) found that the metacercariae were killed in acetic acid at concentration of 5 or $10 \%$ within 12 and 6 hours, respectively. Sukontason et al. (1998) stated that 5\% acetic acid has no killing effect on trematode EMC within 3hours.

Vinegar is one of the oldest fermented food items enjoyed by man and widely used in food industry. In our study, commercial vinegar ( $5 \%$ Conc.) has no killing effect on ECM (MI $\geq 1$ within 24hour), (Table 4). Murrell, (2002) reported that commercial vinegar (4\% Conc.) has no killing effect on $O$. viverrini EMC within one hour.

The results summarized in Table 4 revealed that common salt $(\mathrm{NaCl})$ could kill the EMC $(\mathrm{MI} \leq 1)$ at Conc. 30, 20\% within 1and 2 hours, respectively. Lower Conc. (10 and 5\%) have $\mathrm{MI} \geq 1$ within 24 hour (no killing effect). The sodium chloride micro environment effect on ECM was investigated by other researchers. Wiwanitkit et al. (2002) stated that degeneration of all Haplorchinae spp. metacercariae took approximately 3 hours by marination in 5\% sodium chloride. With The Far East indigenous Stellantchasmus flacatus metacercariae, Wongswad et al. (2005) found that the worms were killed in $\mathrm{NaCl} 20,30,40 \%$ solutions within 12, 6 and 2 hours, respectively.

Fish processors are in need of methods to eliminate parasites in fish rather than cooking. In our study, different storage and processing methods were evaluated as control measures of the ECM in $O$. niloticus within 24 hour. Chilling and freezing are the normally employed methods for fish preservation. Cold storage of $O$. niloticus at $5^{\circ} \mathrm{C}$ for 24 hours dose not affect the viability of ECM (MI $\geq 1$ within $24 \mathrm{~h}$ ), (Table5).

Youssef et al. (1993) found that chilling muscle pieces of fish at $4 \dot{c}$ for 24 hour has no killing effect on trematode EMC. Abdalah et al. (2009) stated that it took 11-15 days of storage at $5^{\circ} \dot{\mathrm{c}}$ to achieve complete loss of viability of four different trematode ECM while Wiwanitkit et al. (2002) found that refrigeration of freshwater fish for approximately 5hours resulted in degeneration of all Haploirchinae spp. 
By freezing, killing of parasites depends on several factors. The temperature of freezing process, length of time that fish is held frozen and type of parasite appear to be the most important, FDA (2001). In the present study storage of $O$. niloticus at $-10{ }^{\circ} \mathrm{C}$ for 12 hours resulted in complete loss of ECM viability (Table5).

With the same fish species, Abdallah et al. (2009) mentioned that it took longer time (16h of storage at $10{ }^{\circ} \mathrm{C}$ ) to gain complete loss of Dilpostomatidae ECM viability. A shorter time (5h) was enough to degenerate all Haplorchinae spp. ECM in freshwater fish, Wiwanitkit et al. (2002).

Marinating is the process of soaking foods in a seasoned, often acidic, liquids with or without cooking. The aim of marinating is not only to inhibit the action of bacteria but also tenderize the connective tissue, EFSA (2010). In this study the present authors investigated the effect of soaking of $O$. niloticus in acetic acid on viability of EMC. The data summarized in (Table5), revealed that it took two hours after soaking of fish in acetic acid for one minute to gain $\mathrm{MI} \leq 1$ (killing effect). In general, little was known about the effect of acid on fish trematodes, mainly ECM., Zviagina and Beer (1997) found that $3 \%$ acetic acid was minimally effective in suppressing the viability of $O$. felineus ECM while $6 \%$ concentration was about 6 times higher. Wiwanitkit et al. (2002) reported that marinating freshwater fish for approximately 3 hours was enough to degenerate Haplorchinae spp. EMC.

Dry salting was the most effective processing mean in our study. It could kill the ECM in O. niloticus muscles within one hour, (Table, 5). Parasites vary in their response to common salt, research studies indicated that parasites can be eliminated at high salt concentrations for a short period, some of them can also be killed at low salt content. That will depend on fat content, temperature, amount of salt, salt composition, et. (Mol and Ozden 2004).

Fan (1998) stated that keeping the freshwater fish in heavy salt (fish/salt=10gm/3gm) may not be effective in the prevention of clonorchiasis. Sukontasoy et al. (1998) found that $10 \% \mathrm{NaCl}$ has no killing effect on trematode ECM in fish within 3 hours. Murrell (2002) reported that dry salting was lethal for anisakids within ten minutes of direct contact.

Knowledge about the $\mathrm{pH}$ of fish flesh may give valuable information about its condition. The $\mathrm{pH}$ value of seafood varies from 5.8-7.2 depending on struggling at time of harvesting but normal variation is of $\mathrm{pH}$ 5.8-6.5 Ali (2011). The present data summarized in Table 6 verify that acetic acid soaked fish had a significant lower $\mathrm{pH}(\mathrm{p}<0.05)$ values compared to control. Lowering the $\mathrm{pH}$ by acid application is the chief application in foods, (Ahmed, 1999).
Sensory assessment has always played a key role in quality and freshness evaluation in fish industry. In our study, the five attributes tested by panelists are given in Table 6. Except for barely detected unpleasnt odour (barely vinegar like odour) scores, sensory attribute of cooked Tilapia treated with acetic acid did not differ significantly compared with control (p<0.05).In this respect, Marshall and Kim (1996) stated that catfish fillets treated with $2 \%$ acetic acid for 5-60seconds were liked less by sensory panels than control due to acidic odour. The detected vinegar-like odour in treated fish in our study did not significantly affects the overall acceptability compared with control, and judged as acceptable Table 6. Ahmed (1999) concluded that acetic acid should not be used in concentration higher than $2 \%$ because consumer may reject such acid treated fish as they alter sensor quality especially odour and color of such fish. our experiment revealed that with $5 \%$ acetic acid fish still acceptable by panelists and that may lead to the fact that intact fish less affected by acid than filleted fish.

\section{CONCLUSION}

From the present study it could be concluded that the fresh water fishes (O. niloticus) are subjected to infection with Cryptosporidium, Acanthocephalus and encysted metacercariae of different trematode worms, which could be transmitted to the consumers causing dangerous disease. Therefore such parasites must be well controlled in order to avoid their transmission to man. This study also revealed that some fish processing methods or treatments are adequate to kill ECM in O. niloticus. Storage of fish at $-10{ }^{\circ} \mathrm{C}$ for 12 hour, marination of fish in $5 \%$ acetic acid for one minute and waiting for 2 hours or dry salting for one hour using table salt (sodium chloride /fish=3gram/10gram).

\section{REFERENCES}

Abd-Allah, A.R.A. (2009): Parasites Encystation in some Crustacea and Fish. Ph. D. Thesis, Fac. Vet. Med., Zagazig Univ., Egypt.

Abdalla, K.F.; Hamadato, H.H.A. and EL-Hayawam, I.A.H. (2009): Effect of different temperatures on viability of seven encysted metacercariae recovered from freshwater fish in Qualyobia, Egypt. J. Egypt. Soci. Parasitol.39 (2)413-420.

Abd El-Maksoud, A.S. (1992): Zoonotic agents in Marine fish marketedin Dumyat. M.V.Sc. Thesis, Fac. Vet. Med., Zagazig Univ., Egypt.

Abdel-Mawla, H.I. and El-Ekiaby, W.T. (2012): Some studies on parasitic infection among Morone labrax (Seabass fish) as bio-indicator of environmental conditions. Egypt. J. Agricult. 2 (3) $1-15$.

Abd-El-Rahman, A.M.M. (2005): Studies on prevailing parasitic diseases among some 
fresh water fishes caused by Digenetic trematodes SCVMJ, VIII (1) 13- 24.

Adams, A.M.; Murrell, K.D. and Gross, J.H. (1997): Parasites of fish and risks to public health. Rev. Sci. Tech., 16 (2): 652-60.

Ahmed, A.M. (1999): The use of edible organic acids to extend the storage life of meat and fish. A review article. SCVM J.II (2)253-261.

Aiello, E.S. and Mays, A. (1998): The Meck Veterinary Manual. Eighth edition, Merck and Co., Inc, Whitehouse station, N.J., USA.

Ali, F.H.M. (2011): Quality evaluation of some fresh and imported frozen seafood. Advance J. Food Sci. and Technol. 3 (1)83-88.

Alvarez-Pellitero P.; Quiroga, M.I. and SitjaBobadilla, A. (2004): Cryptosporidium scophthalmin. sp. (Apicomplexa: Cryptosporidiidae) from cultured turbot Scophthalmus maximus: Light and electron microscope description and histopathological study. Dis Aquat Organ 62:133-145.

Al-Taee, A.F. (2008): Endoparasites of the fresh water fish Liza abu in Mosul, Iraq. Iraq J V Sc. 22(1):25-29.

Amer, O.H. (1996): Observation on some heterophid trematodes encysted in Egyptian marine fish. J. Egypt. Vet. Med. Ass., 56 (3): 301-311.

Amin, A.M. (2005): Studies on the role of shellfish in transmitting some parasites to man. M. V. Sc. Thesis Zoonoses, Fac. Vet. Med. Zagazig Univ.

Arafa, M.I.; Shaheen, M.S. and Monib, M.M. (2005): Studies on some clinostomatid metacercariae from Tilapia nilotica in Assiut Governorate. Assiut Vet. Med. J. 51. (107)218-227.

Baruš, V.; Peňáz, M. and Kohlmann, K. (2002): Cyprinus carpio (Linnaeus, 1758). In: P.M. Banaresku and H.J. Paepke (Eds.), The Fresh water Fishes of Europa. Cyprinidae, Carassius to Cyprinus Gasterosteidae.

Duijn, V. (1973): Diseases of fishes. Life books, charles. C. Thomas Publ. 11, p 372 .

EFSA (European Food Safety Authority) 2010: Scientific opinion risk assessment of parasites in fishery products. EFSA J.8 (4)1543.

Eissa, I.A.M.; Diab, A.S. and Badran, A.f. (1996): Studies on some internal parasitic diseases among wild and cultured Oreochromis niloticus fish. 7th Sci. Cong. 17-19.p 274-289.

Eissa, I.A.; Badran, A.F. and Mohamed, S.Y. (2010): Enteric Helminthes Infections in Cultured and Wild Oreochromis niloticus in Ismailia Province, Egypt. Agricult.and Vet. Sci. Qassim Univ. 2(3)99-110.

El-Naffar, M.K.; Sauod, M.E. and Hassan, I.M. (1983): A general survey of the helminth parasites of some fishes from lake Naser of Asswan A.R. Egypt. Assiut Vet. Med. J. 11, (21): 141-148.

El-Naffar, M.K. and El-Shahawi, G.A.Z. (1986):
Studies on the metacercariae of the Nile fishes at El-Minia Province, A.R. Egypt. Assiut Vet. Med. J. 15. (30) 46:58.

El-Shahawi, G.A.Z. (1983): Studies on some fishes as intermediate hosts of helminth parasites of some birds and mammals. Master Degree of Science. Fac. Science, El-Minia Univ.

Elsheikha, H.M. and Elshazly, A.M. (2008): Hostdependent variations in the seasonal prevalence and intensity of heterophyid encysted metacercariae (Digenea: Heterophyidea) in brackish water fish in Egypt .Vet. Parasitol., 153: 65-72.

Fan, P.C.C. (1998): Viability of metacercariae of Clonorchis sinensis in frozen or salted freshwater fish .Int.J. Parasitol. 28 (4) 603-605.

FDA (2001): Fish and fisheries products Hazard controls guidance $3^{\text {rd }}$ edit. Food and Drug Adminstration, Center for Food Safety And Applied Nutrition Washington, Dc, USA.

Ferrari- Hoeinghaus, A.P.; Fakemoto, R.M. and Oliveira, L.C. (2006): Host relationships of monogeneans in gills of Astyanax altiparanae and Rhamdia quelen of the sao Francisco verdadeiro river, Brazil. Parasite., 13:315-320.

Green, B.W.; El-Nagdy, Z. and Hebicha, H. (2002): Evaluation of Nile tilapia pond mangment strategies in Egypt.Aquaculture Research 33:1037-1048

Hassan, A.A.; Shoukary, N.M. and El-Motayam, M. (2008): Efficacy of five chemicals on Fasciola gigentica encysted metacercariae. J. Egypt. Soc. Parasitol. 38 (3) 919- 928.

Haustein, T.; Lawes, M.; Harris, E. and Chiodini, PL. (2009): An eye-catching acanthocephalan. Clinical microbiology and infection 16:6.

Healy, G.R. (1970): Trematodes transmitted to man by fish, frogs and crustacean. J. Wildlife Diseases 6: $255-261$.

Hefnawy, Y. (1989): Cryptosporidium affection of fresh water Nile fish in Assiut province. Assiut Vet Med J. 21: 130-133.

Henriksen, A. and Pohlenz, J.F.L. (1981): Staining of Cryptosporidium by a modified Ziehl-Neelsen technique. Acta Vet Scand. 22: 594-596.

Hernandez, E.M.; Constantino, C. and Gracia, M. (1998): Gill lesions in common carp, Cyprinus carpio in Mexico due to the metacercariae of Centocestus formosonus. J. Fish Dis., 21: 229-232.

Huss, H.H.; Ababouch, L. and Gram, L. (2003): Assessment and mangement of seafood safety and quality. Food Agriculture Organization (FAO)fiseries technology.

Hussein, E.A.M. (2007): Role played by fish in transmitting helminth human parasites M. Sc. Thesis, in Parasitology, Fac. Med. Assiut Univ.

Ibrahim, M.M. (2012): Variation in parasite infra- 
communists of Tilapia zillii in relation to some biotic and abiotic factors. Int. J. Zoo. R. 8 (2) 59-70.

Khattab, M.H. (1990): Some studies on Platyhelminthes infesting some freshwater fishes in Egypt M.V.Sc. Thesis, Fac. of Vet. Med., Alex. Univ.

Mahdy, O.A.; Essa, M.A. and Easa, M.E.S. (1995): Parasitological and pathological studies in Tilapia $s p$. from Manzala Egypt. J. Comp. Pathological and Clin. Pathol., 8: 131-145.

Mahmood I.O. (2012): Identification of Cryptosporidium sp. in common carp (Cyprinus carpio)in Tikrit city, Iraq. J. Tikrit Unive. Agric. Scien 31: 23.

Marshall, D.L. and Kim, C.R. (1996): Ological and sensory analysis of refrigerated catfish fillets treated with acetic and lactic acids. Food quality 19(4)317-329.

Martin, G.V.; Juan, V.G.; Augustin, R.A. and Salvador, G.G. (2009): Diplostomiasis in cultured and wild Tilapia (Oreochromis niloticus) in Guerrero State, Mexico.

Mol, S. and Ozden, O. (2004): Tuzlama. In:C Varlik (ED)Su urunleti Isleme Teknolojisi.Istanbul Universitesi, Yayn No.4465,Su urunleri Fak No:7,Istambul:182-202.

Murrell, K.D. (2002): Fisborne zoonotic parasites epidemiology,detection and elimination. Lactic and bacteria in fish preservation. In:H.A.Bremmer (Ed), Safety and quality issues in fish processing. Wood head publishing Ltd. CRCpress, New York: 114-141.

Nasr, M. (1941): The occurance of Prohemistomum vivax infection in man, with redescription of the parasite. Lab. and Med. Prog., 2: 135-149.

O'Donoghue, P.J. (2005): Cryptosporidium and cryptosporidiosis in man and animals. Int. J. Parasitol. 25:139-195.

Pillay, T.V. (1990): Aquaculture Principles and Parasites. Fishing News Book, Blackwell Science, Oxford, UK, 575pp.

Prawang, T. (2001): Evaluation of the efficiency of raw papaya juice and pineapple juice on digestion of fish for detection of metacercariae.Chang Mai University. Ms Thesis.

Pritchard, M.H. and Kruse, G.O. (1982): The collection and preservation of animal parasites. Tech. Bull. No.1, Harold W. Manter Laboratory. Univ. Nebraska Press, Lincoln, $141 \mathrm{p}$.

Ramadan, H.H. (1991): Effect of Host Species, Sex, Length, Diet and Different Seasons on the Parasitic Infection of Tilapia Fish in Lake Manzalah J.K.A. U.: Mar. Sci. 81:91.

Sallam, K.I. (2007): Chemical, sensory and shelflife evaluation of sliced salmon treated with salts of organic acids.Food Chem.101(2)592-600.
Sayasone, S.; Odematt, P. and Phoumindr, N. (2007): Epidemiology of Opisthorchis viverrini in rural district of South Lao PDR, Trans. R. Soc. Trop. Med. Hyg., 101: 40-47.

Sitjà-Bobadilla, A.; Padros, F. and Aguilera, $C$. (2005): Epidemiology of Cryptosporidium molnari in Spanis gilthead sea bream (Sparus aurata L.) and European sea bass (Dicentrarchus labrax L.) cultures: from hatchery to market size. Appl. Environ. Microbiol. 71:131-139.

Skinner, R.H. (1982): The interrelation of water quality, gill parasites and gill pathology of some fish from South Biscayne Bay Florida .Fishery Bull., 80: 269-280.

Sohn, W.M.; Kim, J.A. and Song, H.J. (2005): Two species of Goby, Boleophthalmus pectinirostris and Scartelaos sp., as the new second intermediate hosts of Heterophyid fluke in Korea. Korean J. Parasitol; 43 (40): 161 .

SPSS (2007): Sample power Statistic, SPSS, 12.01Syntax Reference Guide for SPSS Base. SPSS Inc, 233South Wacker Drive, Chicago, IL.pp111-119.

Sukontason, K.; Methanitikorn, R. and Sukontason, $K$. (1998): Viabilityof metacercariae in Northen Thai traditional foods .South Asian J. Trop. Med. Public Health 29(4)714-716.

Suloma, A. and Ogata, H.Y. (2006): Future of rice fish culture,desert and aquacuture and feeed development in Africa:The case of Egypt as the leading country in Africa.JARQ 40(4) 351-360.

Tada, I.; Otsuji, Y. and Kamiya, H. (1983): The first case of a human infected with an acanthocephalan parasite, Bolbosoma sp. J. Parasitol 69(1)205-208.

Taher, G. (2009): Some Studies on metacercarial infection in Oreochromis niloticus in Assiut Governorate and their role in transmission of some trematodes to dogs. Ass. Univ. Bull. Environ. Res., 12 (1): 63-79.

Waldman, E.; Tzipori, S. and Forsyth, J.R.L. (1986): Separation of Cryptosporidium species oocysts from feces by using a percoll discontinuous density gradient. J Clin Microb .23:199-200.

Williams, H.H. and Jones, A. (1976): Marine helminthes and human health. Commonu. Inst. Helminthol. Misc. Pub 1.

Wiwanikit, V.; Nithiuthai, S. and Suwansaksri, J. (2002): Motility of minute intestinal fluke, Haplorchinae spp.metacercaiae in fish dishes prepared by different uncooked method. Med. GenMed. 4(1) 8.

Wongsawad, C.; Kawin, S. and Wongsawad, P. (2005): Some factors affecting Stellatchsmus falcatus metacercariae in laboratory. South Esast. Asian J. Trop. Med. Publ. Health 
36(supp144)117-119.

Xiao, L.; Fayer, R. and Ryan, U. (2004): Cryptosporidium taxonomy: Recent advances and implications for public health. Clin Microbiol Rev 17:7.

Youssef, H.; EL-Khateib, T. and Fatma, G.S. (1993): Metacercarial infection in the muscles of Tilapia nilotica and Clarias lazera and the effect of some physical and chemical factors on the viability of encysted metacercariae Assiut Vet. Med. J. 85(56)90.

Zviagina, V.V. and Beer, S.A. (1997): The disinfection of fish in the family Cyprinidae of Opishorchis felineus Riv. metacercariae by the combined use of acetic acid and table salt. Med. Parasitol. (Mosk), 1:9-12.

\section{دراسات على الكريبتوسبوريديم ويعض الطفيليات الأخرى التي تصيب الإنسان في اسماك البلطي النيلي في محافظه أسيوط \\ محمود عمار محمد عمار، محسن إبراهيم عرفة \\ Email: mohsenpara22@yahoo.com}

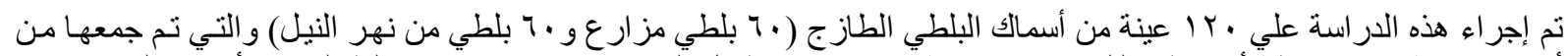

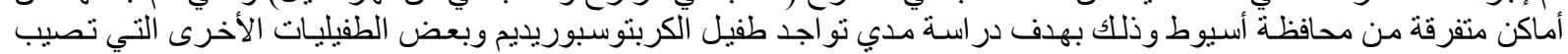

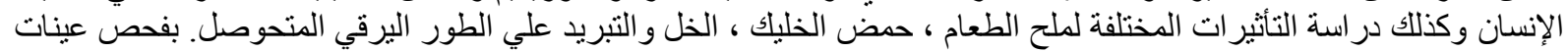

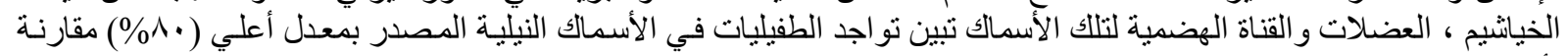

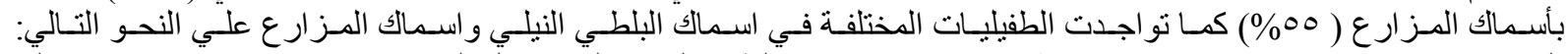

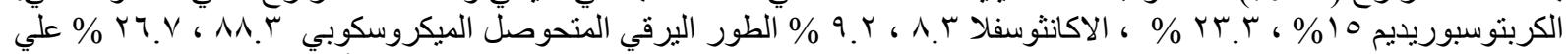

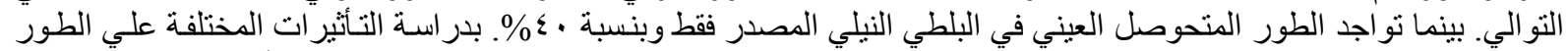

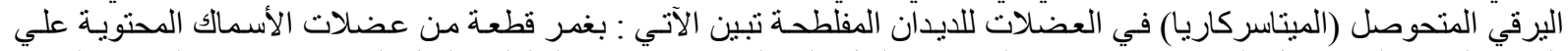

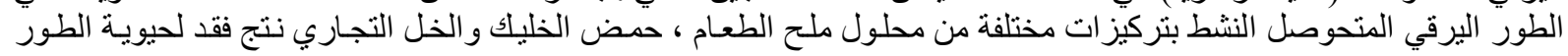

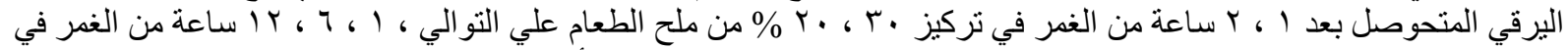

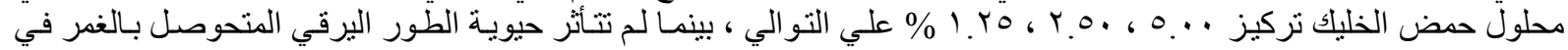

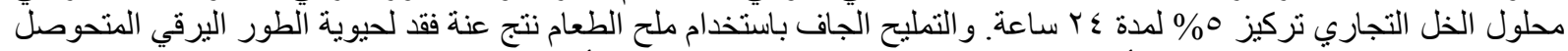

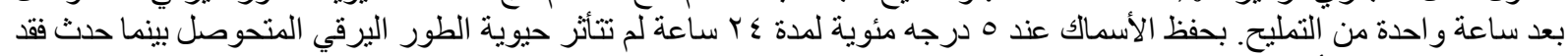

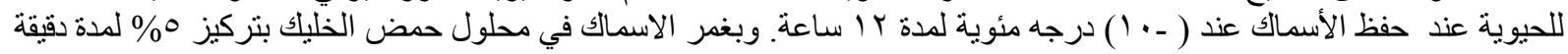

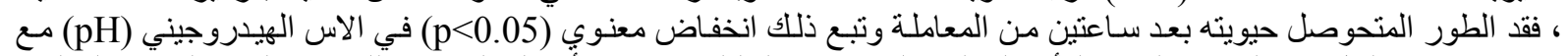

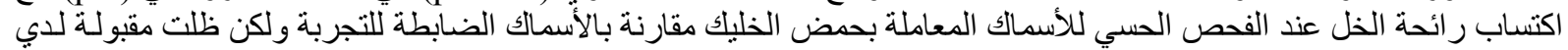
(Sensory evaluation panelist) 